\title{
Vagrant Subantarctic fur seal on the coast of Tanzania
}

\author{
G.J. Greg Hofmeyr ${ }^{1,2 *}$ \& Omar A. Amir ${ }^{3,4}$ \\ ${ }^{1}$ Port Elizabeth Museum at Bayworld, P.O. Box 13147, Humewood, 6013 South Africa \\ ${ }^{2}$ Mammal Research Institute, Department of Zoology and Entomology, \\ University of Pretoria, Pretoria, 0002 South Africa \\ ${ }^{3}$ Institute of Marine Sciences, P.O. Box 668, Zanzibar, Tanzania \\ ${ }^{4}$ Department of Fisheries and Marine Resources, P.O. Box 774, Zanzibar, Tanzania \\ Received 20 January 2010. Accepted 5 March 2010
}

An immature Subantarctic fur seal was sighted on Unguja Island, Zanzibar, Tanzania, in 2008. This is the most northerly record of a vagrant of this species. The nearest breeding colony is on the Prince Edward Islands, $4500 \mathrm{~km}$ distant. While it is likely that this is the natal site of the vagrant due to its proximity and population size, the actual location of origin is unknown. This is the second fur seal sighted in this area. A fur seal of unknown species was sighted on Pemba Island, $30 \mathrm{~km}$ north of the Unguja Island, in 2002. While the species of the latter animal could not be determined, it is likely also a Subantarctic fur seal.

Key words: Arctocephalus tropicalis, distribution, vagrancy, Zanzibar.

Subantarctic fur seal, Arctocephalus tropicalis, Awas sighted on Unguja (or Zanzibar) Island in the Zanzibar Archipelago, Tanzania (Fig. 1). It was first seen ashore at Gwede Beach $\left(5^{\circ} 52^{\prime} \mathrm{S}, 39^{\circ} 21^{\prime} \mathrm{E}\right)$, near Matemwe on 27 June 2008. Two artisanal fishermen observed it being chased into the sea by dogs, whereafter they captured it from a fishing vessel. The owner of a local hotel contacted one of

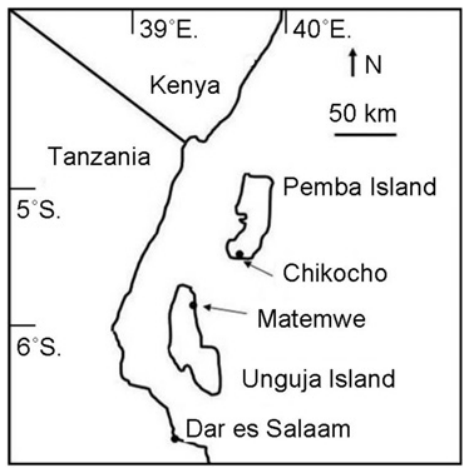

Fig. 1. Locations of confirmed (Matemwe) and suspected (Chokocho) strandings of vagrant Subantarctic fur seals (Arctocephalus tropicalis) in the Zanzibar Archipelago.

*Author for correspondence. E-mail: greg@bayworld.co.za us (O.A.A.) who examined the animal the same day. The animal died two days later. The animal (Fig. 2) was approximately $0.85 \mathrm{~m}$ long, weighed approximately $10 \mathrm{~kg}$ and had a wound of unknown origin on its chest. It was identified from photographs by one of us (G.J.G.H.) as being a Subantarctic fur seal based on a combination of the characteristic colouration of the pelage, the head

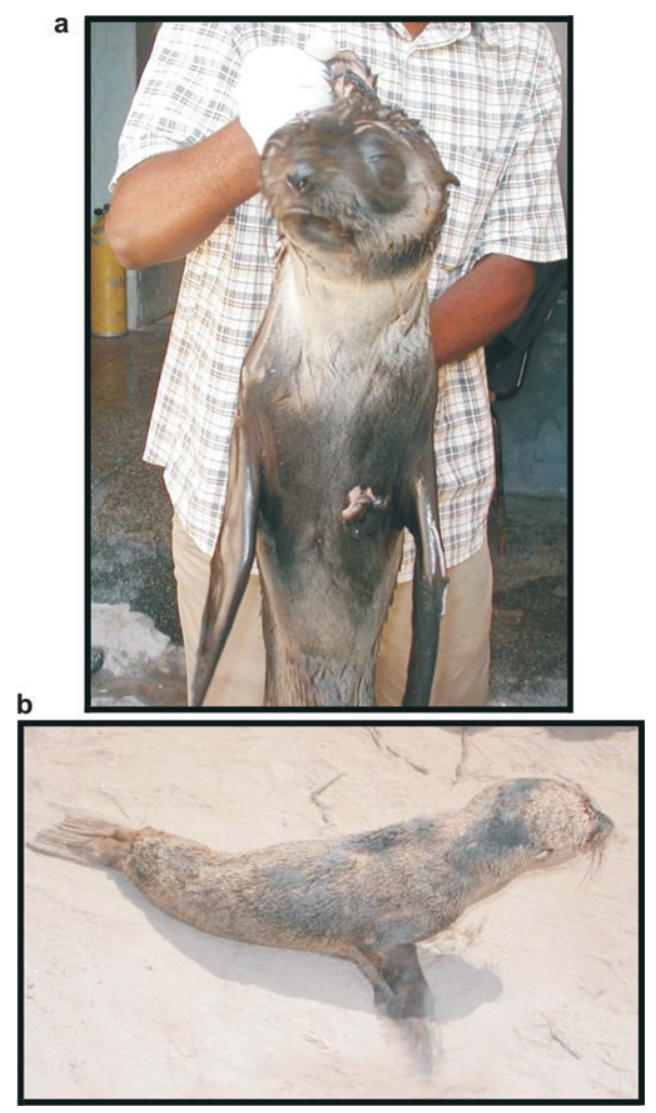

Fig. 2. a, b, Vagrant Subantarctic fur seal (Arctocephalus tropicalis) from Unguja Island, Zanzibar. Photographs: O.A. Amir 


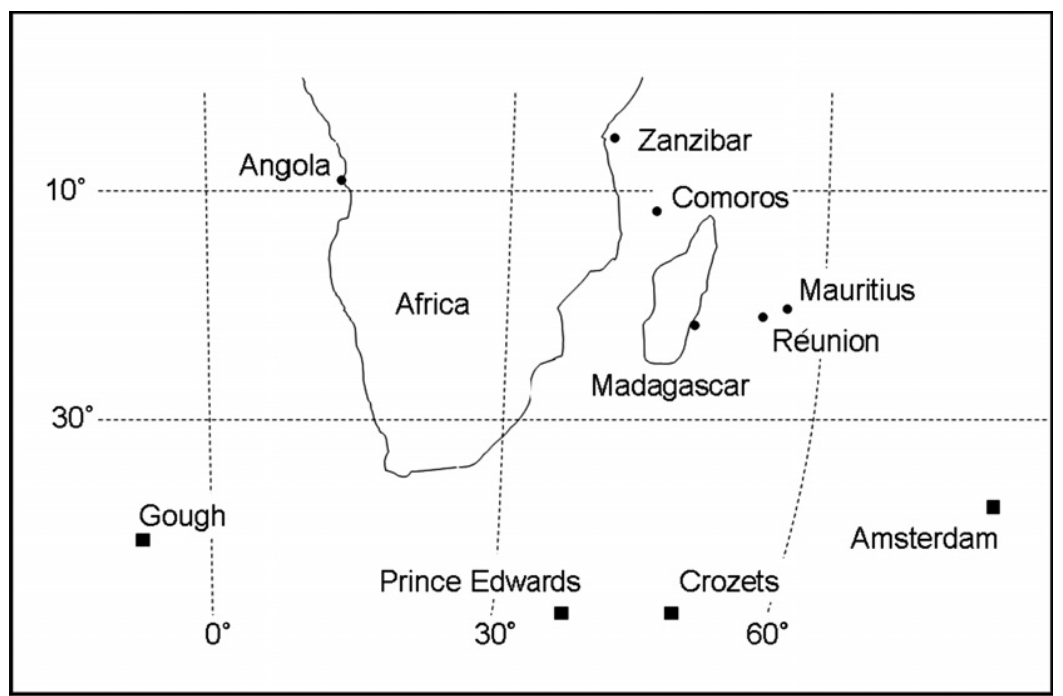

Fig. 3. Map showing location of sites mentioned in the text. Squares indicate Subantarctic fur seal (Arctocephalus tropicalis) breeding colonies while circles indicate the location of selected recorded vagrants.

shape and the relatively large eye size (Condy 1978; Laws 1993).

This is not the first fur seal sighted in the Zanzibar Archipelago. In July 2002 a seal was recorded near Chokocho Village, Pemba Island $\left(5^{\circ} 29^{\prime} \mathrm{S}, 39^{\circ} 38^{\prime} \mathrm{E}\right)$. It was caught on a handline by artisanal fishermen and was killed shortly afterwards. One of us (O.A.A.) examined a video tape of the carcass and recognized it as a fur seal from a published description (Jefferson et al. 1993). Since no records of vagrants from other species of fur seals in the tropical Indian Ocean could be found in the literature, and since Subantarctic fur seals are commonly recorded vagrants (Shaughnessy \& Ross 1980; Pinedo 1988; Gales et al. 1992; Mawson \& Coughran 1999), we suggest that this animal might also be a Subantarctic fur seal.

The record from Unguja Island is the most northerly of a confirmed Subantarctic fur seal. The previous most northerly records of this species are $9^{\circ} 20^{\prime} \mathrm{S}$, for an adult male seen on the coast of Angola (Carr et al. 1985), $9^{\circ} 40^{\prime} \mathrm{S}$ for an individual sighted on the coast of Brazil (Pinedo 1988), $12^{\circ} 30^{\prime} \mathrm{S}$ for an immature animal seen at the Îles Comores (David et al. 1993) and $18^{\circ} 42^{\prime} \mathrm{S}$ for an individual from the coast of Western Australia (Gales et al. 1992). Matemwe is some $370 \mathrm{~km}$ further north than the Angolan sighting, and Chokocho is $30 \mathrm{~km}$ further north still. Both locations are within $650 \mathrm{~km}$ of the Equator.

A number of vagrant Subantarctic fur seals have been recorded in the tropical and subtropical western Indian Ocean in addition to the sighting from the Comores (David et al. 1993). Animals have also been seen on the islands of Madagascar (Garrigue \& Ross 1996), Mauritius and Rodrigues (David \& Salmon 2003). The sources of these animals are possibly related to the proximity of breeding colonies, the abundance of animals at those colonies and prevailing currents. The closest breeding colonies are three groups of islands in the Southern Ocean that lie some 4500-5200 km distant (Fig. 3) and it has been suggested that these are likely sites of origin (David et al. 1993; Garrigue \& Ross 1996; David \& Salmon 2003). While the Prince Edward Islands supports approximately $30 \%$ of global pup production (Bester et al. 2003; Hofmeyr et al. 2006), and Île Amsterdam supports approximately $10 \%$ (Guinet et al. 1994), the contribution of the third site, the Illes Crozet is minimal (Guinet et al. 1994). Subantarctic fur seals, however, may travel far further than this with distances of some $18000 \mathrm{~km}$ recorded (Torres \& Aguayo 1984). Furthermore, Wynen et al. (2000) and Ferreira et al. (2008) showed that Subantarctic fur seals, vagrant to a particular area, need not come from the nearest or the same rookery. The largest population of Subantarctic fur seals, at Gough Island, contributes some $55 \%$ to global pup production of this species (Bester 1987; Bester et al. 2006). While this location lies some $7000 \mathrm{~km}$ distant and is on the other side of the African continent, it is also a possible source of vagrants to the western Indian Ocean. Although prevailing currents are a third 
factor of possible importance in determining the source of vagrants, the long distance these vagrant seals would have travelled in tropical or subtropical waters, should they have followed the prevailing currents of the southern Indian Ocean Gyre, mitigates against this. Furthermore, Subantarctic fur seals of known origin have been recorded at sites which they most likely reached by swimming across currents (Bester 1989; Ferreira et al. 2008).

The length of the animal recorded at Unguja Island indicates that it was immature. A comparison to mass:length data presented in Bester \& Van Jaarsveld (1994) indicates that it was underweight for its length and therefore possibly starving. This is confirmed by an examination of the photographs (Fig. 2). This is unsurprising considering the distance it was found from the normal latitudinal range of this species.

\section{Acknowledgements}

We thank the proprietor of Nyota Beach Bungalows and fishermen in Matemwe for reporting and providing information on the Matemwe seal. We are grateful to Mike Meyer and an anonymous referee for their comments.

\section{REFERENCES}

BESTER, M.N. 1987. Subantarctic fur seal, Arctocephalus tropicalis, at Gough Island (Tristan Da Cunha group). In: Status, Biology and Ecology of Fur Seals. Proceedings of an International Symposium and Workshop, Cambridge, England, 23-27 April 1984 (eds) J.P. Croxall \& R.L. Gentry. NOAA Technical report NMFS 51: 57-60.

BESTER, M.N. 1989. Movements of southern elephant seals and Subantarctic fur seals in relation to Marion Island. Marine Mammal Science 5: 257-265.

BESTER, M.N., RYAN, P.G. \& DYER, B.M. 2003. Population numbers of fur seals at Prince Edward Island, Southern Ocean. African Journal of Marine Science 25: 549-554.

BESTER, M.N. \& VAN JAARSVELD, A.S. 1994. Sex-specific and latitudinal variance in postnatal growth of the Subantarctic fur seal (Arctocephalus tropicalis). Canadian Journal of Zoology 72: 1126-1133.

BESTER, M.N., WILSON, J.W., BURLE, M-H. \& HOFMEYR, G.J.G. 2006. Population trends of Subantarctic fur seals at Gough Island. South African Journal of Wildlife Research 36: 191-194.

CARR, T., CARR, N. \& DAVID, J.H.M. 1985. A record of the sub-Antarctic fur seal Arctocephalus tropicalis in Angola. South African Journal of Zoology 20: 77.

CONDY, P.R. 1978. Distribution, abundance, and annual cycle of fur seals (Arctocephalus spp.) on the Prince Edward Islands. South African Journal of Wildlife Research 8: 159-168.

DAVID, J.H.M., MERCER, J. \& HUNTER, K. 1993. A vagrant Subantarctic fur seal Arctocephalus tropicalis found in the Comores. South African Journal of Zoology 28: 61-62.

DAVID, J.H.M. \& SALMON, L. 2003. Records of the subantarctic fur seal from Rodrigues and Mauritius, Indian Ocean. African Journal of Marine Science 25: 403-405.

FERREIRA, J.M., DE OLIVEIRA, L.R., WYNEN, L., BESTER, M.N., GUINET, C., MARAES-BARROS, N., MARTINS, F.M., MUELBERT, M.M.C., MORENO, I.B., SICILIANO, S., OTT, P.H. \& MORGANTE, J.S. 2008. Multiple origins of vagrant Subantarctic fur seals: a long journey to the Brazilian coast detected by molecular markers. Polar Biology 31: 303-308.

GALES, N.J., COUGHRAN, D.K. \& QUEALE, L.F. 1992. Records of subantarctic fur seals Arctocephalus tropicalis in Australia. Australian Mammalogy 15: 135-138.

GARRIGUE, C. \& ROSS, G.J.B. 1996. A record of a subantarctic fur seal, Arctocephalus tropicalis, from Madagascar, Indian Ocean. Marine Mammal Science 125: 624-627.

GUINET, C., JOUVENTIN, P. \& GEORGES, J-Y. 1994. Long term population changes of the fur seals, Arctocephalus gazella and Arctocephalus tropicalis on subantarctic (Crozet) and subtropical (St Paul and Amsterdam) islands and their possible relationship to El Niño Southern Oscillation. Antarctic Science 6: 473-478.

HOFMEYR, G.J.G., BESTER, M.N., MAKHADO, A.B. \& PISTORIUS, P.A. 2006. Population changes of Subantarctic and Antarctic fur seals at Marion Island. South African Journal of Wildlife Research 36: 55-68.

JEFFERSON, T.A., LEATHERWOOD, S. \& WEBBER, M.A. 1993. Marine Mammals of the World. FAO Species Identification Guide. Food and Agricultural Organisation, United Nations, Rome.

LAWS, R.M. 1993. Identification of species. In: Antarctic Seals: Research Methods and Techniques, (ed.) R.M. Laws, pp. 1-28. Cambridge University Press, Cambridge.

MAWSON, P.R. \& COUGHRAN, D.K. 1999. Records of sick, injured and dead pinnipeds in Western Australia 1980-1996. Journal of the Royal Society of Western Australia 82: 121-128.

PINEDO, M.C. 1988. Ocorrência de Pinípedes na Costa Brasileira. [Occurrence of pinnipeds on the Brazilian coast.]. Garcia de Orta - Serie de Zoologia 15: 37-48.

SHAUGHNESSY, P.D. \& ROSS, G.J.B. 1980. Records of the sub-Antarctic fur seal (Arctocephalus tropicalis) from South Africa with notes on its biology and some observations of captive animals. Annals of the South African Museum 82: 71-89.

TORRES, D. \& AGUAYO, A. 1984. Presence of Arctocephalus tropicalis (Gray 1872) at the Juan Fernandez Archipelago, Chile. Acta Zoologica Fennica 172: 133134.

WYNEN, L.P., GOLDSWORTHY, S.D., GUINET, C., BESTER, M.N., BOYD, I.L., GJERTZ, I., HOFMEYR, G.J.G., WHITE, R.W.G. \& SLADE, R. 2000. Postsealing genetic variation and population structure of two species of fur seal (Arctocephalus gazella and A. tropicalis). Molecular Ecology 9: 299-314.

Responsible Editor: J.H. van Wyk 